\title{
Management of penetrating injuries of the upper extremities
}

\author{
Oscar JF Van Waes, M.D., ${ }^{1}$ Pradeep H Navsaria, M.D., ${ }^{2}$ Renske CM Verschuren, ${ }^{1}$ \\ Laurens C Vroon, ${ }^{1}$ Esther MM Van Lieshout, MSc. Ph.D., ${ }^{1}$ Jens A Halm, M.D. Ph.D., ${ }^{1}$ \\ Andrew J Nicol, M.D. Ph.D., ${ }^{2}$ Jefrey Vermeulen, M.D., MSc., Ph.D. ${ }^{3}$ \\ ${ }^{1}$ Department of Trauma Surgery, Erasmus University Medical Centre, Rotterdam, The Netherlands \\ ${ }^{2}$ Trauma Unit, Groote Schuur Hospital, University of Cape Town, Cape Town, South Africa \\ ${ }^{3}$ Trauma Surgery, Admiraal De Ruyter Hospital, Goes, The Netherlands
}

\section{ABSTRACT}

BACKGROUND: Routine surgical exploration after penetrating upper extremity trauma (PUET) to exclude arterial injury leads to a large number of negative explorations and iatrogenic injuries. Selective non-operative management (SNOM) is gaining in favor for patients with PUET. The present study was undertaken to assess the validity of SNOM in PUET and to present a practical management algorithm.

METHODS: All consecutive patients presenting to a tertiary referral center following PUET were included in this prospective observational cohort study. Patients were managed along Advanced Trauma Life Support (ATLS ${ }^{\odot}$ ) guidelines, and based on clinical manifestations, either underwent emergency surgery or were treated conservatively with or without additional diagnostic investigations. Computed tomography angiography (CTA) was indicated by a preset protocol based on the physical examination.

RESULTS: During the four-month study period, 161 patients with PUET were admitted. Sixteen (9.9\%) patients underwent emergency surgery, revealing 14 vascular injuries. Another 8 (5.0\%) patients underwent vascular exploration following CTA. The remaining patients $(n=137)$ were managed non-operatively for vascular matters. Eighteen (II.2\%) patients required semi-elective surgical intervention for fractures or nerve injuries. During the follow- up, no missed vascular injuries were detected.

CONCLUSION: Neither routine exploration nor routine CTA is indicated after PUET. Stable patients should undergo additional investigation based on clinical findings only. SNOM is a feasible and safe strategy after PUET.

Key words: Emergency surgery, penetrating trauma, upper extremity, vascular injury.

\section{INTRODUCTION}

Penetrating injuries to the extremities account for about $50 \%$ of penetrating traumas, but overall they are still very uncommon in West European countries. ${ }^{[1,2]}$ The low incidence makes it difficult for trauma surgeons to gain experience in its management. Moreover, patients with penetrating injury

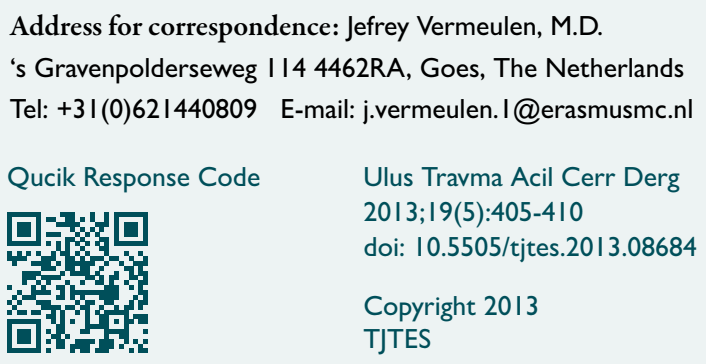

usually present unexpectedly to the emergency department. This could lead to an inappropriate preparation for assessment, especially when the hospital is not an allocated trauma center for such trauma with a protocol treatment strategy.

Penetrating upper extremity trauma (PUET) is considered a difficult injury to manage because vascular and nerve injuries are serious and may significantly impair the patient outcome. [2,3] In the past, routine emergent exploration was common practice for the deeper penetrating trauma, resulting in a large number of unnecessary extremity explorations and iatrogenic injuries. ${ }^{[1,4]}$ Although rapid detection, localization and specification of a vascular injury in these patients are essential for the effective management of PUET, it is ill-advised to perform diagnostic computed tomography angiography (CTA) or conventional angiography in every patient. ${ }^{[5-7]}$ Over $90 \%$ of CTAs in these patients will be negative, representing a large cost as a screening tool. ${ }^{[7]}$ 
Based on the experience from high-volume hospitals in developing countries, selective screening based on physical examination is gaining in favor. The accuracy of the physical examination to detect vascular injury is very high in patients after penetrating trauma. ${ }^{[6,8-10]} \mathrm{Hard}$ signs of a vascular injury (Table I) mandate emergent surgical exploration, or, when the patient is hemodynamically stable, endovascular treatment could be considered. ${ }^{[7,11]}$ Diagnostic CTA is indicated in hemodynamically stable patients with clinical signs of vascular injury (Table I). Similar to the case with penetrating trauma in other body regions, a selective non-operative management (SNOM) protocol should be used in PUET. ${ }^{[2,8,9]}$ Without signs of vascular impairment in PUET, a conservative observational strategy is likely. ${ }^{[8]}$

The present study was undertaken to assess SNOM in PUET in a tertiary referral trauma center (Groote Schuur Hospital, Cape Town), to which over 800 patients with penetrating trauma of the extremities present each year. Based on the results, a management algorithm is proposed and adjusted towards health care in western countries.

\section{MATERIALS AND METHODS}

To create a database, details of all consecutive patients presenting with PUET to the Trauma Center at Groote Schuur Hospital in Cape Town, South Africa, from 6 June 20II to 2 October 2011 (4 months) were prospectively collected using standardized data forms. Inclusion criteria were patients with PUET and age over 18 years. The range of injury that was included was from below the axilla up to the wrist of the upper extremity. Patients who died within 24 hours (hrs) due to other injuries were excluded from the study.

Amongst others, age, gender, mechanism of injury, type of injury (vascular, orthopedic, nerve), clinical manifestations and vitals, indications for additional investigations, treatment strategy, and outcome of all patients were collected and analyzed.

All patients were initially resuscitated along Advanced Trauma Life Support (ATLS) guidelines. Hemodynamically stable patients and patients who stabilized after immediate simple resuscitation were first evaluated with a thorough history and clinical examination. Wounds were described by different anatomic zones of the arm (upper or lower arm, elbow or cubital fossa, anterior-posterior, medial-lateral).

Special investigations were requested when indicated by a preset protocol based on history and clinical manifestations. A routine X-ray was performed in case of gunshot injuries. Indications for CTA were symptoms suggesting vascular injury (hard and soft signs) as found by clinical examination of the upper extremities (Table I) in the presence of a viable limb. If any severe injury was found by additional investigations and surgical care was needed, patients were immediately transferred to the operating room for surgical intervention.
Table I. Signs of arterial injury

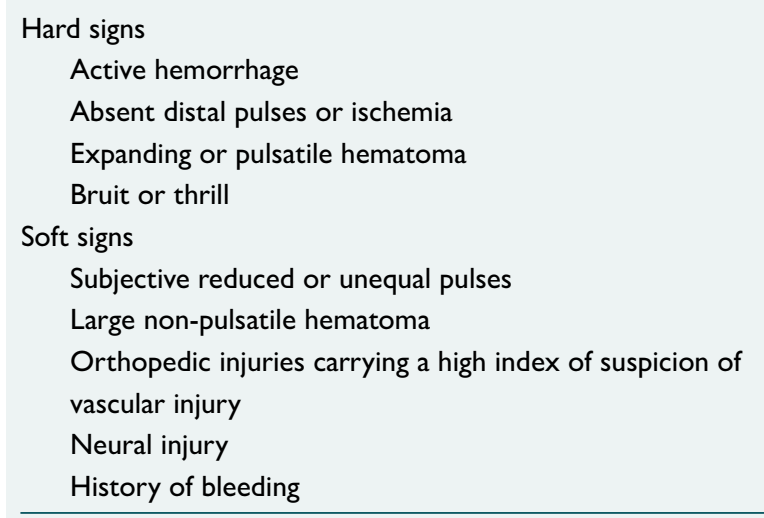

Hemodynamically stable patients with a negative history and clinical examination suggestive of vascular injury were admitted to the trauma surgical ward for observation and were discharged after 24 hours. All patients were informed about alarm symptoms of vascular injury; if these occurred, patients were advised to return to the hospital immediately.

Hemodynamically unstable patients and those with ischemia were immediately transferred to the operating room. In actively bleeding patients, hemorrhage control was attempted by using Foley catheter balloon tamponade (FCBT). ${ }^{[12]}$ If hemorrhage control was not established, surgical exploration of the injured arm followed immediately. If hemorrhage was controlled by FCBT, CTA was performed to detect major arterial injury and, if positive, patients could still be transferred to the operating room or were treated by endovascular options. Without any serious arterial injury, the patient was observed for 24-48 hrs, after which the Foley catheter was removed in the operating room. In case of re-bleeding, surgical intervention was performed.

\section{RESULTS}

A total of 162 patients with PUET presented during the four-month study period. One patient died of accompanying abdominal bleeding within $24 \mathrm{hrs}$ after admission and was excluded from the study. Some patients had multiple wounds to the upper extremities, with a total of 179 wounds in 161 patients (Table 2). Stab wounds (SW) or deeper penetrating glass wounds were found in 128 (79.5\%) patients (I 45 arms) and gunshot wounds (GSW) in the remaining 33 (20.5\%) patients (34 arms).

Sixteen (9.9\%) patients underwent emergency exploration because of active bleeding or hemodynamic instability not improving during initial resuscitation or due to other reasons mentioned in Table 3. In all but two patients, an arterial injury was detected during exploration that required repair.

A total of 24 (14.9\%) patients underwent CTA (Table 3) for a 
Table 2. Demographics of $16 \mathrm{I}$ patients with penetrating upper extremity injury

\begin{tabular}{|c|c|}
\hline Sex ratio (Male/Female) & $|40 / 2|$ \\
\hline Number of upper extremities injured & 179 \\
\hline Median age, years (range) & $27(|6-7|)$ \\
\hline \multicolumn{2}{|l|}{ Penetrating upper extremity injury } \\
\hline Deep glass injury & 13 \\
\hline Stab wound & 132 \\
\hline Gunshot wound & 34 \\
\hline \multicolumn{2}{|l|}{ Zone of extremity injury } \\
\hline \multicolumn{2}{|l|}{ Right arm } \\
\hline Upper & 30 \\
\hline Elbow, cubital fossa & 6 \\
\hline Lower & 25 \\
\hline Upper and lower & 4 \\
\hline \multicolumn{2}{|l|}{ Left arm } \\
\hline Upper & 53 \\
\hline Elbow, cubital fossa & 4 \\
\hline Lower & 40 \\
\hline Upper and lower & 11 \\
\hline Bilateral injury & 6 \\
\hline \multicolumn{2}{|l|}{ Suspected extremity injury } \\
\hline \multicolumn{2}{|l|}{ Vascular } \\
\hline Emergent exploration' & $16(14)$ \\
\hline Computed tomography angiography' & $24(\mathrm{II})$ \\
\hline \multicolumn{2}{|l|}{ Fracture } \\
\hline X-ray ${ }^{2}$ & $19(10)$ \\
\hline \multicolumn{2}{|l|}{ Nerve } \\
\hline Physical examination ${ }^{2}$ & $35(\mathrm{II})$ \\
\hline \multicolumn{2}{|l|}{ Accompanying penetrating injury } \\
\hline Neck & 14 \\
\hline Neck and chest & 4 \\
\hline Chest & 19 \\
\hline Abdomen & 12 \\
\hline Chest and abdomen & 6 \\
\hline Thigh & 6 \\
\hline
\end{tabular}

I: Values in parentheses are numbers of positive findings; 2: Values in parentheses are numbers of surgical interventions because of injury.

suspected vascular injury. In 2 patients, CTA was performed without relevant indication and neither showed any vascular injury. A total of 3 patients were initially treated with FCBT because of active bleeding. In I patient, hemostasis could not be achieved, and the patient was subsequently emergently surgically treated. The other 2 , in whom hemostasis was achieved, were observed and underwent diagnostic CTA within 24 hrs. Only I of these patients showed an arterial injury, which was repaired during semi-elective exploratory surgery. The Foley catheter of the patient, who did not need to undergo surgery, was removed in the operating room 2 days after the patient's presentation, and no re-bleeding occurred.

Overall, 16 (9.9\%) patients underwent emergency exploration of the upper extremity, including two negative explo-
Table 3. Indications and results of emergent surgical exploration or additional vascular investigations

\begin{tabular}{lc}
\hline Indication for emergency exploration & $\mathbf{n}$ \\
\hline Active hemorrhage or shock & $4(4)$ \\
Absent pulses & $3(3)$ \\
Foley catheter balloon tamponade failure & $1(1)$ \\
Hematoma accompanied with neural injury & $8(6)$ \\
\hline Indication for computed tomography angiography & $\mathbf{n}$ \\
\hline Absent or diminished pulses & $12(6)$ \\
Large hematoma & $3(2)$ \\
Foley catheter balloon tamponade & $2(1)$ \\
Bruit & I (I) \\
Injury at cubital fossa & $3(1)$ \\
Fracture and neural injury & I (0) \\
Not specified & $2(0)$ \\
\hline
\end{tabular}

Values in parentheses are numbers of positive findings of arterial injury.

rations. Eventually, another $8(5.0 \%)$ patients underwent elective surgery for a vascular injury (Table 4); no patients were treated with radiological intervention. One hundred and thirty-seven (85.1\%) patients underwent non-operative management with observation only. Following observation, none of the patients subsequently needed surgical intervention to treat (late-onset) vascular complications. Some of the later-mentioned patients did undergo surgical treatment by orthopedics $(n=10)$ or plastic or neurosurgeons $(n=8)$. In 3 patients, the plastic surgeon joined the trauma surgeon during emergent exploration to repair a nerve injury primarily.

The median hospital stay was 4 days (range, I-30 days). Longer hospital stay was related to associated injuries as listed in Table 2. One patient died of abdominal sepsis after penetrating chest and abdominal injury. Upper extremity-related complications were surgical site infection in 8 of the patients that underwent surgery. Loss of function or other nerve impairment was found in only 5 patients, besides the II patients that underwent surgical repair of damaged nerves. Long-term functional outcome of these II patients was not known at the end of this study. Fractures of the upper extremity after penetrating injury were almost exclusively found after GSW. In I patient, an ulnar shaft fracture was found in a patient with $\mathrm{SW}$ in combination with blunt assault.

\section{DISCUSSION}

In the Netherlands, as in the rest of West Europe, the incidence of penetrating injury is rather low. In Dutch trauma centers, there is definitely much less experience with the management of PUET than, for example, in the United States or South Africa. Due to this low incidence, it is not possible for a trauma surgeon to gain experience with the manage- 
Table 4. Summary of arterial injuries and their management

\begin{tabular}{ll}
\hline Site of injury & Treatment \\
\hline $\begin{array}{l}\text { During emergency exploration } \\
\text { Brachial artery }\end{array}$ & $\begin{array}{l}\text { Venous interposition graft with fasciotomy (5) } \\
\text { Primary repair (3) }\end{array}$ \\
Radial artery & Primary repair with fasciotomy (3) \\
& Ligation (2) \\
After computed tomography angiography & Ligation with fasciotomy \\
Axillary artery & \\
Occlusion & \\
False aneurysm & Primary repair \\
Brachial artery & Primary repair \\
Occlusion & \\
AV fistula with basilica vein & Venous interposition graft (2) \\
Active bleeding & Venous interposition graft \\
False aneurysm & Primary repair (2) \\
False aneurysm & Primary repair \\
Posterior circumflex humeral artery & Conservative \\
Active bleeding & \\
Ulnar artery & Conservative \\
False aneurysm & Conservative \\
\hline
\end{tabular}

Values in parentheses are number of patients, if more than one.

ment and treatment of this kind of trauma. Protocol management of PUET is lacking, causing obscurity, disagreement in diagnostic and treatment options, and an insufficient or incomplete management of this trauma patient. The lack of protocol assessment of patients suffering PUET increases the risk of mistakes and hampers good outcome.

In trauma centers that do treat a high number of patients with penetrating trauma, SNOM is becoming more and more accepted. ${ }^{[6,8]}$ SNOM is based on clinical examination and additional investigations. Together, they have shown to be a reliable indicator of clinically significant injury, with a sensitivity of $99 \%$ and a negative predictive value of $99 \%$ in patients with PUET. ${ }^{[5,13]}$

The present study was done in a high-volume, tertiary referral trauma center for penetrating injuries, which manages about 800 patients with penetrating extremity injury each year. The management protocol for assessing and treating patients with PUET is based essentially on hemodynamic status, together with a thorough physical examination. Initial management of GSW and SW is similar, except that X-ray to rule out a fracture of the upper extremity is standard care in GSW patients. Adjuvant CTA is only indicated based on hard and subtle signs of vascular injury found during clinical assessment in hemodynamically stable patients.

At present, in most trauma centers, CTA has replaced angiography as the preferred diagnostic tool in assessment of vascular injuries. An advantage of using angiography, however, is the possibility of interventional procedures, if indicated, during the same session. Nevertheless, for diagnostic evalua-

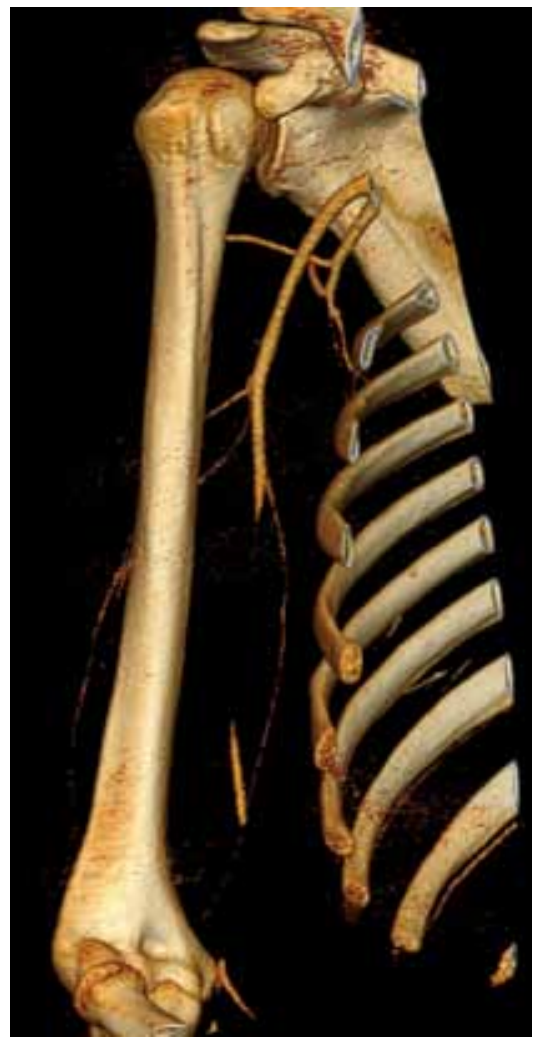

Figure 1. Computed tomography angiography of a patient without peripheral pulses on physical examination, showing an occlusion of the brachial artery, which was subsequently surgically reconstructed with venous interposition grafting. 
tion of PUET, CTA has several advantages over conventional angiography. ${ }^{[14,15]}$ It is relatively fast, minimally invasive, has fewer potential complications, and is available in most trauma centers in western countries. Moreover, no support of additional physician staff is required, unlike with conventional angiography, and structures other than vascular structures can be visualized on CTA (Figure I). Most important, it is a reliable and accurate investigation with a sensitivity and specificity of over $90 \%$ and $100 \%$, respectively, a positive predictive value of almost $100 \%$, and a negative predictive value of 98\%. ${ }^{[16,17]}$ Therefore, CTA is more and more becoming the diagnostic tool of choice during the initial evaluation of stable patients with vascular injury and thus very useful in patients with PUET.

In this study, the SNOM protocol for penetrating extremity injury was correctly executed with good persistence. Violation of the hospital protocol was noted in a total of 10 patients. Two patients with no signs of vascular injury underwent CTA. As neither showed vascular lesions, they were successfully treated conservatively. On the other hand, eight patients with hematoma accompanied by nerve injury underwent immediate surgical exploration. As they were hemodynamically stable, they should have undergone protocol CTA. Two of those patients showed no vascular injury during exploration, and surgery could have been withheld if CTA had been performed.

The use of FCBT has been shown to be beneficial in penetrating injury of the neck and extremities. ${ }^{[12,18]}$ This procedure allows for rapid hemorrhage control and stabilization of patients, giving the opportunity to visualize any vascular injury on CTA. Especially venous injuries are compliant to FCBT, and in those patients, FCBT is often the definitive treatment. ${ }^{[12]}$ If hemostasis cannot be achieved by $\mathrm{FCBT}$, emergency exploration is indicated. Alternatively, temporary hemorrhage control can be achieved by using a tourniquet or hemostatic dressings before surgery or FCBT. After FCBT, diagnostic CTA should be performed; CTA is useless with a tourniquet in place. In this study, FCBT was used in three patients, of whom one failed, and the patient subsequently underwent emergent exploration with brachial artery repair.

Vascular observational management after PUET was applied in $85 \%$ of patients without or after CTA assessment. During the follow-up, none of the patients who was conservatively treated and observed presented with a missed vascular injury. This indicates that initial conservative management (or SNOM) of patients with PUET is feasible and safe.

The total surgical treatment rate was $26 \%$ (24 vascular injuries, 10 fractures, 8 exclusive nerve injuries), indicating that PUET should be considered a serious injury that requires intensive and thorough assessment of the arm. ${ }^{\left[{ }^{[9]}\right.}$ The prevalence of vascular injury after PUET that requires interven-

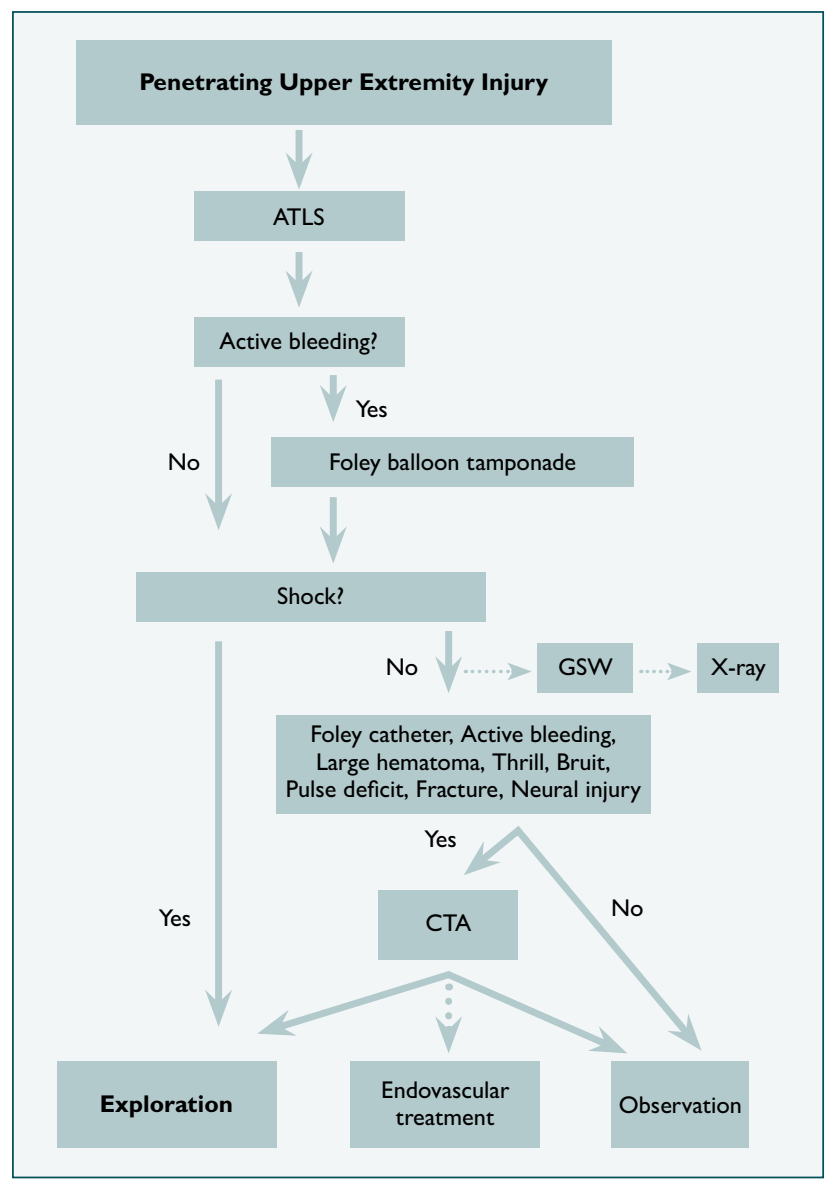

Figure 2. Algorithm for initial management of patients with penetrating upper extremity injury. ATLS: Advanced Trauma Life Support; GSW: Gunshot wounds; CTA: Computed tomography angiography.

tion is $15 \%$. Frequently, PUET is associated with penetrating injuries (this study, in $38 \%$ of cases) that possibly need to be managed first or that distract the physician's attention away from the injuries of the upper extremity. Eventually missed or even delayed assessment of PUET may significantly impair patient outcome. This is best prevented by protocol-driven management strategies. In penetrating trauma, the different protocols could be combined.

In summary, clinical examination has a high negative predictive value for the absence of any injury, and can therefore dictate CTA to prove or exclude clinically significant vascular injuries in PUET. The low failure rate in this study further validates the SNOM protocol for initial management of PUET. Following the results of this study, we present a simple and practical algorithm for the initial management of PUET in western countries (Figure 2). Vascular assessment after GSW should not be different from that of SW, although one must realize that the severity of injury usually is more extensive due to high energy, and an X-ray is performed to exclude a fracture.

Conflict of interest: None declared. 


\section{REFERENCES}

1. Doody O, Given MF, Lyon SM. Extremities-indications and techniques for treatment of extremity vascular injuries. Injury 2008;39:1295-303.

2. Manthey DE, Nicks BA. Penetrating trauma to the extremity. J Emerg Med 2008;34:187-93.

3. Zellweger R, Hess F, Nicol A, Omoshoro-Jones J, Kahn D, Navsaria P. An analysis of 124 surgically managed brachial artery injuries. Am J Surg 2004;188:240-5.

4. Geuder JW, Hobson RW 2nd, Padberg FT Jr, Lynch TG, Lee BC, Jamil $Z$. The role of contrast arteriography in suspected arterial injuries of the extremities. Am Surg 1985;51:89-93.

5. Inaba K, Branco BC, Reddy S, Park JJ, Green D, Plurad D, et al. Prospective evaluation of multidetector computed tomography for extremity vascular trauma. J Trauma 2011;70:808-15.

6. Frykberg ER, Dennis JW, Bishop K, Laneve L, Alexander RH. The reliability of physical examination in the evaluation of penetrating extremity trauma for vascular injury: results at one year.J Trauma 1991;31:502-11.

7. Keen JD, Dunne PM, Keen RR, Langer BG. Proximity arteriography: cost-effectiveness in asymptomatic penetrating extremity trauma. J Vasc Interv Radiol 2001;12:813-21.

8. Dennis JW, Frykberg ER, Veldenz HC, Huffman S, Menawat SS. Validation of nonoperative management of occult vascular injuries and accuracy of physical examination alone in penetrating extremity trauma: 5 - to 10-year follow-up. J Trauma 1998;44:243-52.

9. Van Waes OJ, Cheriex KC, Navsaria PH, van Riet PA, Nicol AJ, Vermeulen J. Management of penetrating neck injuries. Br J Surg 2012;99:14954.

10. Dragas M, Davidovic L, Kostic D, Markovic M, Pejkic S, Ille T, et al.
Upper extremity arterial injuries: factors influencing treatment outcome. Injury 2009;40:815-9.

11. Stone WM, Fowl RJ, Money SR. Upper extremity trauma: current trends in management. J Cardiovasc Surg (Torino) 2007;48:551-5.

12. Navsaria P, Thoma M, Nicol A. Foley catheter balloon tamponade for life-threatening hemorrhage in penetrating neck trauma. World J Surg 2006;30:1265-8.

13. Peng PD, Spain DA, Tataria M, Hellinger JC, Rubin GD, Brundage SI. $\mathrm{CT}$ angiography effectively evaluates extremity vascular trauma. Am Surg 2008;74:103-7.

14. Wallin D, Yaghoubian A, Rosing D, Walot I, Chauvapun J, de Virgilio C. Computed tomographic angiography as the primary diagnostic modality in penetrating lower extremity vascular injuries: a level I trauma experience. Ann Vasc Surg 2011;25:620-3.

15. Patterson BO, Holt PJ, Cleanthis M, Tai N, Carrell T, Loosemore TM; London Vascular Injuries Working Group. Imaging vascular trauma. Br J Surg 2012;99:494-505.

16. Miller-Thomas MM, West OC, Cohen AM. Diagnosing traumatic arterial injury in the extremities with CT angiography: pearls and pitfalls. Radiographics 2005;25:133-42.

17. Seamon MJ, Smoger D, Torres DM, Pathak AS, Gaughan JP, Santora TA, et al. A prospective validation of a current practice: the detection of extremity vascular injury with CT angiography. J Trauma 2009;67:238-44.

18. Ball CG, Wyrzykowski AD, Nicholas JM, Rozycki GS, Feliciano DV. A decade's experience with balloon catheter tamponade for the emergency control of hemorrhage. J Trauma 2011;70:330-3.

19. Brown KR, Jean-Claude J, Seabrook GR, Towne JB, Cambria RA. Determinates of functional disability after complex upper extremity trauma. Ann Vasc Surg 2001;15:43-8.

\title{
KLINIKK ÇALIŞMA - ÖZET
}

\section{Üst ekstremitelerin penetran yaralanmalarının tedavisi}

\section{Dr. Oscar JF Van Waes, ${ }^{1}$ Dr. Pradeep H Navsaria, ${ }^{2}$ Renske CM Verschuren, ${ }^{1}$ Laurens C Vroon, ${ }^{1}$ Dr. Esther MM Van Lieshout, ${ }^{1}$ Dr. Jens A Halm, ${ }^{1}$ Dr. Andrew J Nicol, ${ }^{2}$ Dr. Jefrey Vermeulen ${ }^{1,3}$}

\author{
1Erasmus Üniversitesi Tıp Merkezi, Travma Cerrahisi Bölümü, Roterdam, Hollanda \\ ${ }^{2}$ Cape Town Üniversitesi, Groote Schuur Hastanesi, Travma Bölümü, Cape Town, Güney Afrika \\ ${ }^{3}$ Admiraal De Ruyter Hastanesi, Travma Cerrahisi, Goes, Hollanda
}

AMAÇ: Arter yaralanmasını dışlayan üst ekstremite penetran yaralanmasının rutin cerrahi eksplorasyonu çok sayıda olumsuz sonuçlu açınımlara ve iyatrojenik yaralanmalara yol açmaktadır. Bu hastalarda seçici cerrahi dışı tedavi giderek daha fazla oranda benimsenmektedir. Bu çalışma bu cerrahi dışı tedavinin geçerliliğini değerlendirme ve pratik bir algoritma sunma amacıyla gerçekleştirilmiştir.

GEREÇ VE YÖNTEM: Penetran üst ekstremite yaralanmaları ardından üçüncü basamak sevk merkezine gelen tüm ardışık hastalar bu ileriye dönük gözlemsel kohort çalışmasına alındı. Hastalar ATLS ${ }^{\odot}$ kılavuzları ve klinik belirtilerine göre yönetildi, ya acil cerrahiye alındı veya ek tanısal araştırmalar yapılmadan veya gerekirse yapılarak konservatif tedavi uygulandı. Fiziksel incelemeye göre daha önce hazırlanan bir protokole uyarak bilgisayarlı tomografik anjiyografi (BTA) gerekli oldu.

BULGULAR: Dört aylık çalışma döneminde penetran üst ekstremite yaralanması olan I6। hasta çalışmaya alındı. On dördünde damar yaralanmaları olan 16 (\%9.9) hastaya acil cerrahi girişim yapıldı. Ayrıca 8 (\%5) hastaya BTA sonrası vasküler eksplorasyon uygulandı. Geri kalan hastaların (n= I37) vasküler sorunları cerrahi dışı yöntemlerle tedavi edildi. Kırıkları veya sinir yaralanmaları nedeniyle I 8 (\%। I.2) yarı-seçici cerrahi girişim gerekti. İzlem döneminde herhangi bir damar yaralanmasının atlanmadı̆̆ı belirlendi.

TARTIŞMA: Üst ekstremitelerin penetran yaralanmalarından sonra rutin eksplorasyon veya BTA'ya gerek yoktur. Durumu stabil hastalar yalnızca klinik bulgularına göre ek araştırmalardan geçmelidir. Seçici cerahi dışı tedavi bu yaralanmalardan sonra uygun ve güvenli bir tedavi stratejisidir.

Key words: Acil cerrahi, penetran yaralanma, üst ekstremite, damar yaralanması. 